\title{
KEBIJAKAN RESTORATIVE JUSTICE MELALUI PENDEKATAN DIVERSI PADA TAHAP PENYIDIKAN DALAM RANGKA MEMBERIKAN PERLINDUNGAN HUKUM TERHADAP ANAK YANG BERKONFLIK DENGAN HUKUM
}

\author{
Zulkarnain S \\ Alumni Program Studi Doktor Ilmu Hukum \\ Pascasarjana Universitas Islam Bandung \\ (Dosen Fakultas Hukum Universitas Islam Riau) \\ Email : zulkar67@gmail.com
}

\begin{abstract}
Abstrak: Proses penyelesaian perkara anak melalui sistem peradilan pidana dapat menimbulkan stigma negatif serta berpengaruh pada masa depan anak, dengan lahirnya Undang-Undang Sistem Peradilan Pidana Anak, maka penyelesaian perkara anak yang berkonflik dengan hukum mengedepankan model restorative justice, yaitu pemulihan ke kondisi semula dan pemidanaan sebagai jalan terakhir, sehingga perlu didahulukan cara lain diluar pengadilan salah satunya adalah dengan cara diversi. Tujuan penelitian adalah untuk menjelaskan implementasi restoratif justice melalui pendekatan diversi pada tahap penyidikan dalam rangka memberikan perlindungan hukum terhadap anak yang berkonflik dengan hukum ,serta untuk menjelaskan bentuk perlindungan hukum yang ideal bagi anak yang berkonflik dengan hukum pada masa yang akan datang. Penelitian menggunakan pendekatan penelitian hukum empiris, sifat penelitian deskriptif ,pengumpulan data dilakukan dengan teknik studi lapangan dan studi kepustakaan. Teknik analisis data bersifat yuridis kualitatif. Hasil penelitian ditemukan bahwa Implementasi restoratif justice melalui pendekatan diversi pada tahap penyidikan di Polresta Pekanbaru dilakukan dengan cara non litigasi, berupa penyelesaian perdamaian secara keluargaan dengan cara musyawarah yang melibatkan pelaku anak, korban ,keluarga pelaku/ korban dan pihak lain yang terkait untuk mencari penyelesaian yang adil . Diversi menekankan pada pemulihan hak korban serta mendorong anak yang berkonflik dengan hukum untuk bertanggung jawab atas tindakan yang dilakukannya.
\end{abstract}

Kata Kunci : Perlindungan, Keadilan, Restoratif Justice, Diversi

\begin{abstract}
The settlement process of children's cases through the criminal justice system can cause negative stigma and affect their future. With the emergence of Child Criminal Judicial System Law, the settlement of cases of children in conflict with the law puts forward the restorative justice model, namely restoration to its original condition and punishment as the last resort. Hence, it is necessary to prioritize other methods outside the court, one of which is by way of diversion. In line with this, this study was conducted to explain the implementation of restorative justice through a diversion approach at the investigation stage to provide legal protection for children in conflict with the law, and to elucidate the form of ideal legal protection for children in conflict with law in the future. This study used an empirical legal research approach using descriptive research as its nature, through field study and library study as its data collection technique. The data analysis technique used qualitative juridical technique. The result showed that the implementation of restorative justice through a diversion approach at the investigation stage at Pekanbaru Polresta was conducted in a non-litigation manner, in the form of family peace settlement by means of deliberation involving child perpetrators, victims, the perpetrators/victims' families, and other related parties to find fair resolution. A
\end{abstract}


Zulkarnain S, Kebijakan Restorative Justice Melalui Pendekatan Diversi Pada Tahap Penyidikan...

diversion approach emphasizes on restoring the rights of victims and encouraging children who are in conflict with the law to be responsible for their actions.

Keywords: Protection, Justice, Restorative Justice, Diversion

\section{A. PENDAHULUAN}

\section{Latar belakang}

Anak sebagai bagian dari generasi muda merupakan penerus cita-cita perjuangan bangsa dan sumber daya manusia bagi pembangunan nasional ( Ediwarman, Peradilan Anak di Persimpangan Jalan Dalam Persfektif Viktimology ( belajar dari kasus Raju) Jurnal Mahkamah, Fakultas Hukum UIR.Vol.18 No.1, April 2006, Pekanbaru, : 8).

Anak harus dipenuhi kebutuhan pokoknya agar mereka tidak frustasi dan frustasi merupakan sumber utama timbulkan kenakalan remaja.

(IS Susanto, 1991 : 39).

Setiap anak mempunyai harkat dan martabat yang di lindungi oleh hukum. Perlindungan ini perlu karena anak merupakan bagian masyarakat yang mempunyai keterbatasan secara fisik dan mental. (Marlina, 2012 : 42).

Perlindungan hukum terhadap anak mencakup lingkup yang sangat luas yang meliputi berbagai kebebasan dan hak asasi manusia (Barda Nawawi Arief, 2005 : 153).

Masyarakat modern yang serba kompleks, sebagai produk kemajuan teknologi, mekanisasi, industrialisasi dan urbanisasi memunculkan banyak masalah sosial. Sering dijumpai anak melakukan kenakalan ataupun perkelahian karena masa anak anak adalah masa transisi menuju masa dewasa. Semakin tinggi tingkat budaya maka semakin modern pula kejahatan dalam bentuk, sifat dan pelaksanaannya. (Aswarni Adam, Upaya mengatasi Tindak Perkelahian Anak Didik dalam Masa Krisis, Jurnal Mahkamah, Fakultas Hukum UIR, Vol.11 No.1. Pekanbaru, 2000, : 35). Fenomena meningkatnya perilaku tindak kekerasan yang dilakukan anak seolah olah tidak berbanding lurus dengan usia pelaku oleh karena itu berbagai usaha pencegahan perlu 
Zulkarnain S, Kebijakan Restorative Justice Melalui Pendekatan Diversi Pada Tahap Penyidikan...

dilakukan. (Nandang Sambas, 2010 : 10).

Perkembangan kejahatan di provinsi Riau khususnya Pekanbaru sangat mengkhawatirkan. Kepolisian daerah ( Polda ) Riau pada tahun 2017 menerima laporan polisi sebanyak 1.176 kasus kriminal baik yang dlakukan oleh orang dewasa maupun anak-anak. Polres yang paling banyak menerima laporan polisi adalah Polresta Pekanbaru sebanyak 297 kasus kriminal . Kasus yang telah diselesaikan oleh Polresta Pekanbaru sebanyak 193 kasus kriminal ( 153 kasus orang dewasa dan 40 kasus anak ).Kejahatan yang terjadi di kota Pekanbaru sebagian pelakunya adalah anak remaja dan kaum muda. (https://www.jawa pos.com.jpg. Pelaku kejahatan Jalanan di Pekanbaru di dominasi Kaum muda, di akses tanggal 7 Oktober 2018, Jam 22.30 Wib).

Berdasarkan data dari

Polresta Pekanbaru bahwa kejahatan yang dilakukan oleh anak bervariasi setiap tahun, hal ini dapat di lihat dari tabel di bawah ini :
Tabel : 1

Jenis kejahatan anak di wilayah hukum Polresta Pekanbaru Periode tahun 2014 - 2017

\begin{tabular}{|l|l|c|c|c|c|c|}
\hline No. & Jenis kasus & $\begin{array}{c}\text { Tah } \\
\text { un } \\
\mathbf{2 0 1} \\
\mathbf{4}\end{array}$ & $\begin{array}{c}\text { Tah } \\
\mathbf{u n} \\
\mathbf{2 0 1} \\
\mathbf{5}\end{array}$ & $\begin{array}{c}\text { Tah } \\
\mathbf{u n} \\
\mathbf{2 0 1} \\
\mathbf{6}\end{array}$ & $\begin{array}{l}\text { Tah } \\
\mathbf{\text { }}\end{array}$ & $\begin{array}{l}\text { Ke17 } \\
\text { gan } \\
\text { jumlah } \\
\text { kasus }\end{array}$ \\
\hline 1 & Pencurian & 10 & 27 & 17 & 13 & 67 \\
\hline 2 & $\begin{array}{l}\text { Pencurian } \\
\text { dengan } \\
\text { pemberatan }\end{array}$ & 7 & 3 & 8 & 6 & 24 \\
\hline 3 & Narkotika & 3 & 5 & 8 & 10 & 26 \\
\hline 4 & Penadahan & 0 & 0 & 3 & 5 & 8 \\
\hline 5 & $\begin{array}{l}\text { Pencemaran } \\
\text { nama baik }\end{array}$ & 2 & 0 & 0 & 4 & 6 \\
\hline 6 & Penganiayaan & 3 & 1 & 2 & 2 & 8 \\
\hline & Jumlah total & 25 & 36 & 38 & 40 & 139 \\
\hline
\end{tabular}

Sumber data : Reskrim Polresta Pekanbaru tahun 2017

Berdasarkan data dari tabel.1 diatas bahwa jenis kejahatan yang dilakukan oleh anak dalam rentang waktu tahun 2014 sampai dengan tahun 2017 adalah sebanyak 139 kasus dengan rincian bahwa tindak pidana pencurian 67 kasus, pencurian dengan pemberatan 24 kasus, narkotika 26 kasus, penadahan 8 kasus, pencemaran nama baik 6 kasus dan tindak pidana penganiayaan 8 kasus.

Tabel : 2

Persentase anak yang diversi pada tahap penyidikan Di wilayah hukum Polresta Pekanbaru

\begin{tabular}{|c|c|c|c|c|}
\hline No & Tahun & $\begin{array}{c}\text { Jumlah } \\
\text { kasus anak } \\
\text { yang } \\
\text { berkonflik } \\
\text { dengan } \\
\text { hukum }\end{array}$ & $\begin{array}{c}\text { Jumlah } \\
\text { kasus } \\
\text { anak } \\
\text { yang } \\
\text { diversi }\end{array}$ & $\begin{array}{c}\text { Persentase } \\
(\%)\end{array}$ \\
\hline 1 & 2014 & 25 & 8 & $32 \%$ \\
\hline 2 & 2015 & 36 & 22 & $61 \%$ \\
\hline 3 & 2016 & 38 & 6 & $16 \%$ \\
\hline 4 & 2017 & 40 & 26 & $65 \%$ \\
\hline 5 & Jumlah & 139 & 62 & \\
\hline
\end{tabular}

Sumbe sumber data : Reskrim Polresta Pekanbaru tahun 
Zulkarnain S, Kebijakan Restorative Justice Melalui Pendekatan Diversi Pada Tahap Penyidikan...

Berdasarkan data diatas, menggambarkan bahwa intensitas kasus Anak yang Berkonflik Dengan Hukum yang terjadi di wilayah hukum kepolisian Resort kota Pekanbaru ternyata cukup tinggi dan setiap tahun bervariasi , Berdasarkan data pada tabel 2 tersebut diatas,terlihat dengan jelas, bahwa sebagian Anak yang Berkonflik Dengan Hukum dijatuhkan pidana penjara, berarti diversi tidak tercapai.

Kejahatan bukanlah suatu variabel yang berdiri sendiri (Zul Akrial, Kejahatan Korporasi Sebagai Kajian Kriminologi Masa Depan, Jurnal Mahkamah Fakultas Hukum UIR, Vol 3 N0.1 Pekanbaru, 2003, : 191).

tetapi saling berkaitan dengan yang lain. Kejahatan merupakan bentuk penyimpangan perilaku atas aturan-aturan yang kerap menimbulkan kerugian baik bagi si pelaku sendiri maupun bagi masyarakat luas. (Imran Siswadi, Penerapan Sanksi Pidana terhadap Penyalahgunaan Narkotika di kalangan Anak-anak, Jurnal EQUITABLE, Jurnal Ilmiah : Jurisprudence Approach, Fakultas Hukum UMRI. Vol. 1 No.1. Pekanbaru, 2016, : 177).
Penanganan terhadap Anak yang Berkonflik Dengan Hukum haruslah dilakukan secara berbeda dengan orang dewasa, (Randy Pradityo, Restorative Justice dalam Sistem Peradilan Pidana Anak, Jurnal Hukum dan Peradilan. Volume 05 No.3, November 2016, Badan Penelitian dan Pengembangan Hukum dan Peradilan Mahkamah Agung RI. Jakarta, 2016 : 321).

Untuk itu secara paradigma penanganan yang berlaku melalui Undang-Undang No.3 Tahun 1997 tentang pengadilan anak, adalah sama sebagaimana penanganan orang dewasa, dengan model retributif justice, yaitu penghukuman sebagai pilihan utama atau pembalasan atas tindak pidana yang telah dilakukan. (M.Nasir DJamil, 2013 : 3)

Kajian pada tataran akademis yang paradigmatik tentang sistem peradilan pidana anak, dikenal beberapa paradigma yang terdiri; Retributive paradigm, individual treatment paradigm, dan restorative paradigm, yang masing-masing menunjukkan karakternya. (Purniati, Mamik Sri Supatmi dan Ni Made Martini Tinduk, 2005 : 66).

Secara dogmatis, pidana dipandang sebagai pengimbalan atau 
Zulkarnain S, Kebijakan Restorative Justice Melalui Pendekatan Diversi Pada Tahap Penyidikan...

pembalasan terhadap kesalahan si pembuat, (Dey Ravena, 2017 : 155).

tindakan itu dimaksudkan untuk melindungi masyarakat terhadap kejahatan yang dilakukan sipembuat. Penjatuhan sanksi pidana terhadap pelaku tindak pidana memiliki tujuan di satu sisi untuk memberikan penderitaan atau membuat jera, tetapi di sisi lain juga agar membuat pelanggar dapat kembali hidup bermasyarakat sebagaimana layaknya. Dua sisi inilah yang dikenal dalam hukum pidana sebagai " Pedang bermata dua". (Niniek Suparni, $2007:$ 12).

Setelah lahirnya UndangUndang Sistem Peradilan Pidana Anak ( SPPA ) maka pendekatan kasus Anak Berkonflik dengan Hukum, seharusnya mengedepankan model restorative justice, yaitu pemulihan ke kondisi semula, dan pemidanaan sebagai jalan terakhir,sehingga perlu didahulukan cara lain di luar pengadilan, salah satunya adalah dengan cara diversi, yakni pengalihan penyelesaian perkara anak dari proses peradilan pidana ke proses di luar peradilan pidana. Diversi merupakan kebijakan yang dilakukan untuk menghindari pelaku dari sistem peradilan pidana formal. (Sri Rahayu, Diversi sebagai Alternatif Penyelesaian Perkara Tindak Pidana yang di lakukan Anak dalam Perspektif Sistem Peradilan Pidana Anak, Jurnal Ilmu Hukum, Fakultas Hukum Universitas Jambi.Volume 6 No.1, Februari $2015: 130)$.

Ide diversi bagi pelaku anak adalah untuk menyediakan alternatif yang lebih baik dibanding dengan prosedur resmi beracara di pengadilan. (Setya Wahyudi, Implementasi Ide Diversi Dalam Pembaharuan Sistem Peradilan Pidana Anak di Indonesia,Genta Publishing, Yogyakarta, 2011 : 58).

Diversi ini menjadi jalan keluar yang tepat agar anak tidak di bawa ke pengadilan. Untuk itu diversi haruslah menjadi kewajiban dalam penanganan anak yang berkonflik dengan hukum dalam setiap penanganan, baik pada tingkat penyidikan, penuntutan sampai dengan pemeriksaan perkara di sidang pengadilan.

Pergeseran perhatian hukum pidana dan sistem peradilan pidana kepada korban kejahatan memang mempunyai landasan yang rasional . (Edi Setiadi, Menguji Peranan Sistem Peradilan Pidana Dalam 
Zulkarnain S, Kebijakan Restorative Justice Melalui Pendekatan Diversi Pada Tahap Penyidikan...

Memberikan Keadilan dan Kepastian Hukum bagi Anak Korban Kejahatan, Makalah disampaikan dalam Seminar Nasional Perlindungan Hukum Terhadap anak yang menjadi korban kekerasan, yang di selenggarakan oleh Program Doktor Ilmu Hukum, Pasca Sarjana Universitas Islam Bandung, bertempat di Hotel Holiday Inn Bandung, pada tanggal 23 Januari 2016, Hlm. 8).

Pertama akan tercipta sistem hukum pidana dan sistem peradilan pidana yang komprehensif berupa perhatian yang sama baik kepada pelaku kejahatan maupun terhadap korban kejahatan, kedua sesuai dengan prinsip bahwa hukum itu dibuat untuk melindungi semua warga negara, maka sistem peradilan pidana harus dapat menyeimbangkan kepentingan orang yang tersangkut dengan hukum yakni kepentingan pelaku dan korban, alasan ketiga adalah bahwa konflik hukum pidana telah terjadi pergeseran hukum pidana yaitu dari paradigma retributif justice kepada paradigma restorative justice. Konsepsi kejahatan dipahami sebagai pelanggaran terhadap kepentingan individu serta adanya restitusi sebagai bagian pemidanaan (Ibid).

Berdasarkan dari kondisi tersebut diatas, penulis ingin memfokuskan penelitian ini dengan judul "Kebijakan Restorative Justice melalui pendekatan diversi pada tahap penyidikan dalam rangka memberikan perlindungan hukum terhadap anak yang berkonflik dengan hukum ".

\section{Identifikasi Masalah}

Berdasarkan uraian yang
telah dikemukakan dalam latar
belakang diatas, maka dapat
dirumuskan identifikasi masalah
sebagai berikut:

a. Bagaimanakah implementasi restorative justice melalui pendekatan diversi pada tahap penyidikan berdasarkan UU No 11 tahun 2012 tentang Sistem Peradilan Pidana Anak, dalam rangka memberikan perlindungan hukum terhadap anak yang berkonflik dengan hukum ?

b. Bagaimana bentuk perlindungan hukum yang ideal dalam melakukan 
Zulkarnain S, Kebijakan Restorative Justice Melalui Pendekatan Diversi Pada Tahap Penyidikan...

$$
\begin{aligned}
& \text { penyelesaian perkara } \\
& \text { anak yang berkonflik } \\
& \text { dengan hukum pada } \\
& \text { masa yang akan datang? }
\end{aligned}
$$

\section{Tujuan Penelitian}

Dengan uraian diatas tujuan penelitian dapat dirumuskan secara ringkas sebagai berikut :

a. Untuk dapat menjelaskan implementasi restorative justice melalui pendekatan diversi pada tahap penyidikan berdasarkan UU No 11 tahun 2012 tentang Sistem Peradilan Pidana Anak, dalam rangka memberikan perlindungan hukum terhadap Anak Yang Berkonflik Dengan Hukum.

b. Untuk menjelaskan bentuk perlindungan hukum yang ideal dalam melakukan penyelesaian perkara Anak Yang Berkonflik Dengan Hukum pada masa yang akan datang.

\section{B. PEMBAHASAN}

\section{Implementasi restoratif} justice melalui pendekatan diversi pada tahap penyidikan berdasarkan UU No 11 Tahun 2012, dalam rangka memberikan

\begin{tabular}{lrr} 
perlindungan & hukum \\
terhadap Anak & Yang \\
Berkonflik & Dengan \\
Hukum. & \\
\hline
\end{tabular}

Penyidikan adalah serangkaian tindakan penyidik (pejabat polisi negara RI atau pejabat pegawai negeri sipil tertentu) dalam hal dan menurut cara yang diatur dalam undang-undang untuk mencari serta mengumpulkan bukti yang dengan bukti itu membuat terang tentang tindak pidana yang terjadi dan guna menemukan tersangkanya. Sebelum dilakukan penyidikan maka dilakukan penyelidikan oleh penyelidik. (Lihat Pasal 1 angka 1, 2 dan angka 5 UU No. 8 tahun 1981 tentang KUHAP).

Pada tahap penyidikan di kepolisian, pendekatan restorative justice dapat digunakan dan dioptimalkan berdasarkan kewenangan diskresi, yaitu wewenang dari aparatur penegak hukum yang menangani kasus pidana untuk mengambil tindakan meneruskan perkara atau tidak meneruskan perkara, mengambil suatu keputusan pada kondisi tertentu atas dasar pertimbangan dan keyakinan pribadi berdasarkan kebijaksanaan serta bertanggung 
Zulkarnain S, Kebijakan Restorative Justice Melalui Pendekatan Diversi Pada Tahap Penyidikan...

jawab sesuai dengan kewenangan yang dimilikinya.

Dalam melakukan penyidikan anak, diusahakan dilaksanakan oleh polisi wanita, dan dalam beberapa hal, jika perlu dengan bantuan polisi pria. Penyidik Anak, juga harus mempunyai pengetahuan seperti psikologi, psikiatri, sosiologi, pedagogi, antropologi, juga harus mencintai anak dan berdedikasi, dapat menyelami jiwa anak dan mengerti kemauan anak. Menurut penulis dalam praktek pelaksanaannya di Polresta Pekanbaru belum optimal disebabkan kurangnya sumber daya manusia ( personil Polri ) karena Polisi wanita jumlahnya belum mencukupi dan pada unit PPA, jumlah personilnya cuma 11 orang, dengan rincian 3 (tiga) orang Polisi wanita dan 8 (delapan ) orang polisi laki-laki, padahal Polresta Pekanbaru membawahi sebelas (11) Polsek dengan jumlah penduduk yang cukup padat.

Penyidik, wajib memeriksa tersangka dalam suasana kekeluargaan. (Pasal 18 UU No. 11 tahun 2012 tentang UU SPPA). Ketentuan ini menghendaki bahwa pemeriksaan dilakukan dengan pendekatan secara efektif dan simpatik. Efektif dapat diartikan, bahwa pemeriksaannya tidak memakan waktu lama, dengan menggunakan bahasa yang mudah dimengerti, dan dapat mengajak tersangka memberikan keterangan yang sejelas-jelasnya. Simpatik maksudnya pada waktu pemeriksaan, penyidik bersifat sopan dan ramah serta tidak menakut-nakuti tersangka. Tujuannya ialah agar pemeriksaan berjalan dengan lancar, karena seorang anak yang merasa takut sewaktu menghadapi Penyidik, akan mengalami kesulitan untuk mengungkapkan keterangan yang benar dan sejelas-jelasnya. Pada waktu memeriksa tersangka, Penyidik tidak memakai pakaian seragam. Jadi melakukan pendekatan secara simpatik, serta tidak melakukan pemaksaan, intimidasi, yang dapat menimbulkan ketakutan atau trauma pada anak. Penyidikan, merupakan salah satu dari tindakan pemeriksaan pendahuluan menurut KUHAP. Tahap ini tidak saja merupakan dasar bagi pemeriksaan di muka pengadilan, tetapi juga pencerminan tindakan Kepolisian (Penyelidik, Penyidik dan Penyidik Pembantu) terhadap tersangka, yang 
Zulkarnain S, Kebijakan Restorative Justice Melalui Pendekatan Diversi Pada Tahap Penyidikan...

merupakan ukuran perlindungan HAM dan penegakan hukum. Dalam praktek pelaksanaan seperti ini belum sepenuhnya dijalankan oleh personil Polresta Pekanbaru.

Dalam praktik, penyidikan anak dengan suasana kekeluargaan, dapat dikatakan telah cukup difahami oleh para penyidik di Polresta Pekanbaru, tersangka tidak ditakuttakuti, diusahakan suasana yang menyenangkan, atau membuat rasa aman, ditangani dengan sabar, ramah, tidak menciptakan suasana yang menegangkan, dan para penyidik tidak memakai pakaian dinas. Dalam melakukan penyidikan terhadap perkara Anak, Penyidik wajib meminta pertimbangan atau saran dari Pembimbing Kemasyarakatan setelah tindak pidana dilaporkan atau diadukan. Dalam hal dianggap perlu, Penyidik dapat meminta pertimbangan atau saran dari ahli pendidikan, psikolog, psikiater, tokoh agama, Pekerja Sosial Profesional atau Tenaga Kesejahteraan Sosial, dan tenaga ahli lainnya. Dalam hal melakukan pemeriksaan terhadap Anak Korban dan Anak Saksi, Penyidik wajib meminta laporan sosial dari Pekerja Sosial Profesional atau Tenaga
Kesejahteraan Sosial setelah tindak pidana dilaporkan atau diadukan. (Pasal 27 UU No. 11 tahun 2012 tentang UU SPPA). Dalam pelaksanaan praktek di lapangan masih ditemukan kekecewaan masyarakat terhadap kinerja Polri. Ketidak profesionalan polisi sudah sering digugat dalam menangani kejahatan konvensional. (Pudi Rahardi, 2014 : 262).

Terkait dengan anak yang dilaporkan melakukan tindak pidana, dimana Penyidik wajib merahasiakan identitas anak, baik dari pemberitaan di media cetak maupun di media elektronik (Pasal 19 ayat (1) UU SPPA) diakui oleh Penyidik sulit dilaksanakan. Kuatnya pengaruh media masa dan agresivitas wartawan dalam mencari berita terkait kasus anak dengan alasan keterbukaan informasi publik. Hal ini berakibat sulitnya memulai proses diversi karena stigma yang sudah terlanjur melekat pada Anak yang Berkonflik dengan Hukum. (Wawancara dengan Kanit PPA Polresta Pekanbaru, tanggal 3 Januari 2018).

Tindakan Penyidik berupa penangkapan, penahanan dan tindakan lain yang dilakukan mulai 
Zulkarnain S, Kebijakan Restorative Justice Melalui Pendekatan Diversi Pada Tahap Penyidikan...

dari tahap penyelidikan sampai dengan tahap penyidikan, wajib dilakukan secara rahasia. Menurut penulis, UU SPPA tidak memberikan sanksi yang tegas terhadap Penyidik, apabila kewajiban ini dilanggar, dan tidak mengatur akibat hukum terhadap hasil penyidikan. Hal ini mempengaruhi kualitas kerja pihak Penyidik dan sangat berpengaruh terhadap perlindungan anak. Anak dapat menjadi korban ketidaktegasan UU SPPA. Hal ini dapat mengakibatkan kerugian fisik, mental, sosial anak, karena dapat menghambat perkembangan fisik, mental, dan sosial anak dalam pergaulan hidupnya.

Menurut analisa penulis pelanggaran kerahasiaan proses penyidikan Anak, tidak dapat digugat melalui sidang praperadilan, karena pelanggaran tersebut bukan tergolong alasan untuk diajukan pra peradilan. Dalam menanggulangi pelanggaran tersebut, ketika perkara anak diperiksa di persidangan, terdakwa atau penasihat hukum dapat menyampaikan keberatan terhadap surat dakwaan. (Pasal 156 ayat (1) KUHAP). Alasan keberatan adalah, bahwa surat dakwaan tidak memiliki landasan hukum yang benar, karena dibuat berdasarkan hasil penyidikan yang tidak sah, yang pada waktu proses penyidikan tidak dirahasiakan oleh Penyidik. Keberatan tersebut didukung oleh bukti-bukti yang dapat meyakinkan Hakim dalam mengambil keputusan selanya, apabila hakim sependapat dengan terdakwa/penasihat hukumnya.

Menurut penulis pemahaman Penyidik tentang kerahasiaan penyidikan belum benar, sebab sebagian penyidik menyatakan bahwa penyidikan anak yang diduga melakukan kejahatan /kenakalan tidak perlu dirahasiakan, hal ini atas pertimbangan/tujuan agar dapat sama-sama menyelesaikan masalah anak, dan anak tersebut dapat dijadikan sebagai contoh untuk orang lain untuk tidak ditiru dan menjadi pelajaran bagi pihak lain, serta agar para orang tua tidak lagi lalai mengawasi anak-anaknya. Berdasarkan asumsi ini,menurut penulis maka dapat difahami bahwa Penyidik telah memvonis bahwa anak yang bersangkutan telah bersalah dan diperlakukan sebagai orang yang bersalah. Hal ini bertentangan dengan hak asasi manusia. Munculnya fenomena 
Zulkarnain S, Kebijakan Restorative Justice Melalui Pendekatan Diversi Pada Tahap Penyidikan...

penyelewengan wewenang dan tidak menghormati hak asasi manusia yang dilakukan oleh Penyidik menyebabkan asas Praduga tidak bersalah hanya sebagai kata -kata penghibur sejenak bagi tersangka ketika menjalani proses perkara. (Muhammad Schinggyt Tryan , Nyoman Sarikat Putrajaya, Pujiyono, Tinjauan Yuridis terhadap Pelaksanaan Asas Praduga Tidak Bersalah Dalam Proses Peradilan Pidana, DIPONEGORO LAW JOURNAL, Volume 5, Nomor 4, Tahun 2016 : 9).

Hal ini, bertentangan dengan prinsip hukum acara, yaitu asas praduga tak bersalah (presumption of innocence). Asas ini menyiratkan bahwa anak yang berkonflik dengan hukum, belum dapat dianggap bersalah apabila belum ada keputusan pengadilan yang mempunyai kekuatan hukum tetap. Disebut bersifat tetap, apabila tidak ada lagi upaya hukum yang digunakan untuk menerobos keputusan pengadilan tersebut. Pemahaman yang seperti ini, tentu berbahaya bila ditinjau dari aspek perlindungan anak. Pertimbangan penyidikan anak dilakukan secara rahasia, agar perkembangan fisik, mental dan sosial anak, tidak terhambat atau terganggu, sebab secara fisik, mental dan sosial, anak masih lemah sehingga diperlukan kehati-hatian dalam penanganannya.

Menurut Kanit PPA Polresta Pekanbaru bahwa jangka waktu penahanan yang hanya 7 (tujuh ) hari dan dapat diperpanjang 8 ( delapan ) hari sangat singkat, sedangkan untuk mendapatkan saksi dan bukti-bukti guna menyelesaikan BAP membutuhkan waktu yang lama, (Wawancara dengan Kanit PPA Polresta Pekanbaru, tanggal 3 Januari 2018). Ini.merupakan kendala dalam penerapan diversi.

Menurut analisa penulis, jangka waktu penahanan anak menurut Pasal 33 UU SPPA harus di kaji ulang dengan mempertimbangkan alasan kepentingan yang terbaik bagi anak, karena untuk mendapatkan buktibukti yang akurat membutuhkan waktu yang cukup lama, sementara koordinasi antara Penyidik dengan Pihak Bapas belum terjalin dengan baik.Apabila pihak kepolisian lalai / terlambat meminta bantuan Bapas untuk melakukan penelitian masyarakat terhadap anak, maka penyidikan tidak akurat dan terkesan 
Zulkarnain S, Kebijakan Restorative Justice Melalui Pendekatan Diversi Pada Tahap Penyidikan...

buru-buru, karena masa penahanan anak pada tahap penyidikan adalah singkat.yaitu paling lama 7 (tujuh ) hari dan dapat di perpanjang selama 8 ( delapan ) hari. Kurangnya koordinasi antara Penyidik dengan pihak Bapas juga menjadi kendala, karena adanya keluhan dari pihak Bapas dalam hal perdamaian yang dilakukan oleh kepolisian, karena hasil perdamaian sangat jarang dilaporkan ke Bapas, akan tetapi sebaliknya, perdamaian yang dilakukan oleh Bapas belum tentu juga ditanggapi positif oleh polisi, karena mekanisme perdamaian tidak dikenal dalam perkara pidana.

Terkait dengan implementasi diversi dalam tahap penyidikan di Polresta Pekanbaru. Pihak Penyidik telah melakukan diversi dalam beberapa perkara yang ditanganinya. Tindakan yang dilakukan Penyidik di Polresta Pekanbaru adalah sebagai berikut :

1) Terhadap pelaku masih pelajar, tetap menangkap tetapi dinasihati.

2) Apabila pelaku dan korban saling memaafkan dan diberi ganti rugi, maka perkara dihentikan.

3) Jika anak menyesal dan berjanji tidak akan mengulangi serta orang tua sanggup membimbing, maka oleh polisi perkara dihentikan dan pelaku dikembalikan orang tua. (Hasil Wawancara dengan Kasat Reskrim Polresta Pekanbaru, tanggal 15 Januari 2018).

Bentuk diversi yang sudah dilaksanakan di Polresta Pekanbaru adalah menghentikan proses penyidikan,kemudian mewajibkan pelaku untuk melakukan wajib lapor setiap hari Senin dan Kamis selama dua (2) bulan. Hal ini dilakukan sebagai bentuk shock therapy kepada pelaku dan sekaligus sebagai model pengawasan terhadap anak yang berkonflik dengan hukum, mengembalikan anak kepada orang tua, memberikan ganti rugi kepada korban, mengadakan musyawarah dengan melibatkan pelaku/keluarga, korban,orang tua/ wali, Pembimbing Kemasyarakatan dan Pekerja Sosial Profesional.

Pelaksanaan diversi dalam praktek penyidikan di Polresta Pekanbaru diselesaikan secara Non Litigasi yang berupa penyelesaian perdamaian secara keluargaan, selanjutnya pelakunya atau 
Zulkarnain S, Kebijakan Restorative Justice Melalui Pendekatan Diversi Pada Tahap Penyidikan...

keluarganya memberikan ganti rugi, saling memaafkan ataupun perbuatan yang harus dilakukan sesuai dengan hasil musyawarah, misalnya pihak keluarga diwajibkan membimbing anak pelaku tindak pidana tersebut. Namun secara realitas penerapan diversi belum banyak menghasilkan kesepakatan damai,karena ditemukan 5 (lima ) persoalan mendasar yaitu : (a) Kurangnya personil Polri pada unit PPA yang terlatih dalam penanganan perkara anak (b) Kurangnya sarana dan prasarana pendukung bagi penyelesaian perkara anak (c) Kurangnya koordinasi dan persepsi yang berbeda diantara aparat penegak hukum dalam menangani perkara anak (d) UU SPPA tidak mampu menyelesaikan masalah ingkar janji dalam kesepakatan diversi (e) Kurangnya partisipasi dan kesadaran hukum masyarakat dalam penyelesaian perkara anak.

\section{B. Bentuk perlindungan hukum} yang ideal dalam penyelesaian perkara anak yang berkonflik dengan hukum pada masa yang akan datang.

Berikut ini diuraikan bentuk perlindungan hukum yang ideal terhadap penyelesaian perkara anak yang berkonflik dengan hukum pada masa yang akan datang, antara lain :

\section{Perlindungan hukum terhadap anak dengan pendekatan kesejahteraan}

Konsep masa mendatang dalam pembaruan sistem peradilan pidana anak mengacu pada sistem peradilan pidana anak dengan welfare approah (pendekatan kesejahteraan). Adapun yang dimaksud kesejahteraan adalah kesejahteraan anak sebagaimana yang dimaksud oleh undang-undang No. 4 tahun 1997 tentang kesejahteraan Anak. Pasal 1 angka 1 huruf a, yaitu suatu tata kehidupan dan penghidupan anak yang dapat menjamin pertumbuhan dan perkembangannya dengan wajar, baik secara rohani jasmani maupun sosial. Pendekatan yang demikian, juga sejalan dengan pendekatan sejumlah negara di Eropa yang memiliki peraturan perundangundangan tentang juvenile justice, secara umum telah menggunakan pendekatan kesejahteraan. Dengan pendekatan ini pelanggar hukum usia muda sedapat mungkin dijauhkan dari proses penghukuman oleh 
Zulkarnain S, Kebijakan Restorative Justice Melalui Pendekatan Diversi Pada Tahap Penyidikan...

sistem peradilan pidana serta segala tindakan yang akan diambil oleh negara berkaitan dengan pelanggaran yang dilakukan oleh anak tersebut, sedapat mungkin mengedepankan the bests interes of the child. (Stewart Asquith, 1996 : 199).

\section{Perlindungan hukum secara khusus bagi anak}

Pasal 64 ayat (1) UU Nomor

23 Tahun 2002 menentukan bahwa perlindungan khusus bagi anak yang berhadapan dengan hukum meliputi anak yang berkonflik dengan hukum dan anak korban tindak pidana, merupakan kewajiban dan tanggung jawab pemerintah dan masyarakat.

Perlindungan khusus bagi anak yang berhadapan dengan hukum sebagaimana dimaksud dalam ayat (1) dilaksanakan melalui: perlakuan atas anak secara manusiawi sesuai dengan martabat dan hak-hak anak, penyediaan petugas pendamping anak sejak dini, penyediaan sarana dan prasarana khusus, penjatuhan sanksi yang tepat untuk kepentingan yang terbaik bagi anak, pemantauan dan pencatatan terus menerus terhadap perkembangan anak yang berhadapan dengan hukum, pemberian jaminan untuk mempertahankan hubungan dengan orang tua atau keluarga, dan perlindungan dari pemberitaan identitas melalui media massa dan untuk menghindari labelisasi. (Pasal 64 ayat (2) UU Nomor 23 Tahun 2002).

Perlindungan khusus bagi anak yang menjadi korban tindak pidana dilaksanakan melalui: upaya rehabilitasi, baik dalam lembaga maupun di luar lembaga, upaya perlindungan dari pemberitaan identitas melalui media massa dan untuk menghindari labelisasi, pemberian jaminan keselamatan bagi saksi korban dan saksi ahli, baik fisik, mental, maupun sosial; dan pemberian aksesibilitas untuk mendapatkan informasi mengenai perkembangan perkara. (Pasal 64 ayat (3) UU Nomor 23 Tahun 2002).

3. Perlindungan hukum dengan model penanganan anak berbasis masyarakat dengan pendekatan budi pekerti, kearifan lokal dan nilai nilai keagamaan.

Model penanganan anak berkonflik dengan Hukum berbasis masyarakat dengan pendekatan budi pekerti, kearifan lokal dan nilai nilai keagamaan.Hal ini mempunyai 
Zulkarnain S, Kebijakan Restorative Justice Melalui Pendekatan Diversi Pada Tahap Penyidikan...

tujuan untuk terwujudnya pemenuhan hak dasar anak dan perlindungan anak dari kekerasan, ketelantaran, eksploitasi dan diskriminasi, sehingga anak bisa tumbuh kembang dan kelangsungan hidup serta partisipasi anak dapat terwujud. Pendekatan berbasis masyarakat bertujuan untuk membentuk kohesi sosial yang kuat, dengan memelihara budaya lokal yang menjadi landasan untuk maju secara sosial dan ekonomi serta memiliki daya juang yang tinggi. Dengan demikian penanganan Anak Yang Berkonflik Dengan Hukum berbasis masyarakat mempunyai tiga fungsi pokok yaitu sebagai usaha pencegahan kejahatan, pemulihan dan mewujudkan kondisi restorative justice.

Untuk terciptanya perlindungan hukum yang ideal bagi anak,maka di perlukan koordinasi dan kerjasama yang baik dari seluruh elemen masyarakat sehingga diperoleh keseimbangan kegiatan perlindungan anak secara keseluruhan. Perlindungan hukum bagi anak merupakan salah satu cara melindungi tunas bangsa di masa depan. Sehinggga dengan adanya perlindungan anak dapat memberikan pengaruh positif pada bangsa dan Negara.

\section{PENUTUP}

\section{Kesimpulan}

Berdasarkan hasil penelitian yang telah dilakukan, maka dapat diambil kesimpulan sebagai berikut :

a. Implementasi restoratif justice melalui pendekatan diversi pada tahap penyidikan dalam rangka memberikan perlindungan hukum terhadap anak yang berkonflik dengan hukum di Polresta Pekanbaru diselesaikan secara Non Litigasi, namun secara realitas penerapan diversi belum banyak menghasilkan kesepakatan damai,karena ditemukan 5 (lima ) persoalan mendasar yaitu : (a) Kurang nya personil Polri pada unit PPA yang terlatih dalam penanganan perkara anak (b)Kurangnya sarana dan prasarana pendukung bagi penyelesaian perkara anak (c) Kurangnya koordinasi dan persepsi yang berbeda diantara aparat penegak hukum dalam menangani perkara anak (d) UU SPPA tidak mampu menyelesaikan masalah ingkar 
Zulkarnain S, Kebijakan Restorative Justice Melalui Pendekatan Diversi Pada Tahap Penyidikan...

janji dalam kesepakatan

diversi (e) Kurangnya

partisipasi dan kesadaran

hukum masyarakat dalam

penyelesaian perkara anak.

b. Bentuk perlindungan hukum yang ideal dalam penyelesaian perkara anak yang berkonflik dengan hukum pada masa yang akan datang.

1. Perlindungan hukum terhadap anak dengan pendekatan kesejahteraan

2. Perlindungan khusus bagi anak yang dilaksanakan melalui: perlakuan atas anak secara manusiawi sesuai dengan martabat dan hak-hak anak, penyediaan petugas pendamping anak sejak dini, penyediaan sarana dan prasarana khusus, penjatuhan sanksi yang tepat untuk kepentingan yang terbaik bagi anak .

\section{Saran-saran}

Berdasarkan kesimpulan di atas, maka dapat diberikan beberapa rekomendasi saran, sebagai berikut :

1. Agar pemerintah merumuskan ketentuan yang tegas dalam UU SPPA tentang wan prestasi bagi anak yang telah di diversi, dimana pihak pelaku sudah sepakat dengan korban untuk berdamai, tetapi si pelaku ingkar janji dan tidak memenuhi persyaratan yang sudah di sepakati.

2. Agar pimpinan Polri meningkatkan sumber daya manusia baik secara kualitas maupun kuantitas,terutama dalam pelatihan khusus penyidikan anak, supaya profesional dalam menangani perkara anak.

\section{DAFTAR PUSTAKA}

\section{A. Buku-Buku}

Adam, Aswarni, 2000. Upaya mengatasi Tindak

Perkelahian Anak Didik dalam Masa Krisis, Jurnal Mahkamah, Fakultas Hukum UIR, Vol.11 No.1.Pekanbaru.

Asquith, Stewart, 1996. Children and Young People in comflict with the law (ed), jesica Kingsley publishers, London.

Dirdjosisworo, Soedjono, 1996. Anatomi Kejahatan di 
Zulkarnain S, Kebijakan Restorative Justice Melalui Pendekatan Diversi Pada Tahap Penyidikan...

Indonesia, Granesia,

Bandung

DJamil M, Nasir, 2013, Anak Bukan

Untuk Di Hukum : Catatan

Pembahasan UU Sistem

Peradilan Pidana Anak (

UU SPPA ),Sinar Grafika,

Jakarta.

Marlina, 2012, Peradilan anak di Indonesia (Pengembangan Konsep Diversi dan Restorative Justice),Refika

Aditama, Bandung.

Nawawi, Arief Barda, 2005, Beberapa Aspek Kebijakan dan Pengembangan Hukum Pidana. PT Citra Adtya Bakti,Bandung.

Pradityo, Randy, 2016. Restorative Justice dalam Sistem Peradilan Pidana Anak, Jurnal Hukum dan Peradilan. Volume 05 No.3, November 2016, Badan Penelitian dan Pengembangan Hukum dan Peradilan Mahkamah Agung RI. Jakarta.

Purniati, Mamik Sri Supatmi dan Ni Made Martini Tinduk,
2005. Yayasan Pemantau

Hak Anak (children's

Human right Foundation),

kumpulan tulisan, Jakarta.

Rahardi, Pudi, 2017. Hukum Kepolisian, Kemandirian Profesionalisme dan Reformasi Polri, Laksbang Grafika, Surabaya

Ravena ,Dey, 2017 Kebijakan

Kriminal ( Criminal Policy

), Kencana, Jakarta.

S, Zulkarnain, 2016. Teori -teori Hukum Pidana dan Kriminologi, AlMujtahadah Press, Pekanbaru.

Sambas, Nandang, 2010. Pembaharuan Sistem Pemidanaan Anak di Indonesia, Graha ilmu, Yogyakarta.

Schinggyt, Tryan Muhammad. 2016. Nyoman Sarikat Putrajaya, Pujiyono, Tinjauan Yuridis terhadap Pelaksanaan Asas Praduga Tidak Bersalah Dalam Proses Peradilan Pidana, DIPONEGORO LAW 
Zulkarnain S, Kebijakan Restorative Justice Melalui Pendekatan Diversi Pada Tahap Penyidikan...

JOURNAL, Volume 5, Soetedjo, Wagiati dan Melani,

Nomor 4.

Setiadi, Edi, 2016, Menguji Peranan

Sistem Peradilan Pidana

Dalam Memberikan

Keadilan dan Kepastian

Hukum bagi Anak Korban

Kejahatan, Makalah

disampaikan dalam

Seminar Nasional

Perlindungan Hukum

Terhadap anak yang

menjadi korban kekerasan,

yang di selenggarakan

oleh Program Doktor Ilmu

Hukum, Pasca Sarjana

Universitas Islam

Bandung, bertempat di

Hotel Holiday Inn

Bandung.

Siswadi, Imran, 2016. Penerapan

Sanksi Pidana terhadap

Penyalahgunaan

Narkotika di kalangan

Anak-anak, Jurnal

EQUITABLE, Jurnal

Ilmiah : Jurisprudence

Approach, Fakultas

Hukum UMRI. Vol. 1

No.1. Pekanbaru, 2016.
2013Hukum Pidana Anak, edisi revisi, Refika Aditama, Bandung.

Suparni, Niniek, 2007. Eksistensi

Pidana Denda dalam

Sistem Pidana dan

Pemidanaan, Sinar

Grafika, Jakarta.

Susanto, IS, 1991. Kriminologi, Diktat kuliah, Fakultas Hukum Univesitas

Diponegoro, Semarang.

Wahyudi, Setya, 2011. Implementasi Ide Diversi Dalam Pembaharuan Sistem Peradilan Pidana Anak di Indonesia, Genta

Publishing, Yogyakarta.

\section{B. Peraturan Perundang-}

\section{Undangan}

Undang-Undang tahun 1981 tentang

KUHAP

Undang-Undang tahun 2012 tentang SPPA

Undang-Undang Republik Indonesia No. 3 tahun 1997, tentang Pengadilan anak

\section{Jurnal}

Akrial, Zul, Kejahatan Korporasi Sebagai Kajian 
Zulkarnain S, Kebijakan Restorative Justice Melalui Pendekatan Diversi Pada Tahap Penyidikan...

Kriminologi Masa Depan,

Jurnal Mahkamah Fakultas

Hukum UIR, Vol 3 N0.1

Pekanbaru, 2003.

Ediwarman, Peradilan Anak di Persimpangan Jalan Dalam Persfektif Viktimology ( belajar dari kasus Raju) Jurnal

Mahkamah, Fakultas

Hukum UIR.Vol.18 No.1, April 2006, Pekanbaru.

Rahayu, Sri, 2015 Diversi sebagai Alternatif Penyelesaian Perkara Tindak Pidana yang di lakukan Anak dalam Perspektif Sistem Peradilan Pidana Anak, Jurnal Ilmu Hukum, Fakultas Hukum Universitas Jambi.Volume 6 No.1.

\section{Internet}

https://www.jawa pos.com.jpg. Pelaku kejahatan Jalanan di Pekanbaru di dominasi Kaum muda, di akses tanggal 7 Oktober 2018, Jam 22.30 Wib

https;//id.esdifferent.com>Perbedaan antara keadilan restoratif dan keadilan retributif, diakses tanggal 3 Oktober jam 10.00 Wib 